\title{
EFISIENSI USAHA PEMBIBITAN ITIK MODERN DAN TRADISIONAL PADA SKALA RUMAH TANGGA DI KABUPATEN LEBONG
}

\author{
Efficiency Efforts of Modern and Traditional Ducks Breeding on A \\ Household Scale in Lebong District \\ Nuril Anwar, Satria Putra Utama, Reswita \\ Jurusan Sosial Ekonomi Pertanian Universitas Bengkulu \\ nurilanwar@yahoo.co.id
}

\begin{abstract}
The objectives of this research are to determine the income level and to estimate the differencies of income between modern and traditional techniques of breeding by the household in Amen and Lebong Sakti subdistrict, Lebong District. The determination of the amount of revenue is done using analysis of revenues, while for testing whether there are differences in the income of both the duck breeding efforts carried out by different assay analysis of average income. The calculation to determine the level of efficiency of the business activities of breeding ducks using $R / C$ ratio. Based on the results of the research the average revenues of modern ducks nursery is $R p$. 1.331.969,21 for four months, while the average income of the traditional duck breeding attempt amounted to Rp. 1.662.396,66 for four months. After a test of the difference of income between enterprises of modern and traditional duck breeding, breeding of modern ducks revenues smaller revenues equal to the traditional duck breeding where the real differences in the degrees of confidence 95. The average value of the results analysis of $R / C$ ratio in modern duck breeding efforts Lebong is equal to 2.00 while $R / C$ ratio of the traditional duck breeding amounted to 2.15 .
\end{abstract}

Keywords: breeding ducks, households, income and efficiency efforts

\section{PENDAHULUAN}

Ternak itik merupakan salah satu komoditi unggas yang mempunyai peran cukup penting sebagai penghasil telur dan daging untuk mendukung ketersediaan protein hewan. Dalam perkembangannya, usaha itik dapat merupakan usaha pokok bagi sebagian masyarakat dan tidak lagi sebagai usaha sambilan (Juarini et al., 2004). Apriyanto (2011) menjelaskan jika usaha ternak itik sudah memiliki orientasi usaha yang diarahkan dalam suatu kawasan, baik sebagai cabang usaha maupun sebagai usaha pokok, budidaya itik cukup menguntungkan dan dapat dijadikan sebagai sumber pendapatan keluarga. Dalam usaha ternak itik keberadaan bibit itik mutlak sangat diperlukan karena berpengaruh terhadap kelangsungan suatu usaha peternakan itik. Hal ini terutama berlaku bagi sistem pemeliharaan itik intensif 
yang sepenuhnya terkurung dimana jaminan ketersediaan dan kualitas bibit sangat dibutuhkan demi efisiensinya usaha.

Kecamatan Amen dan Lebong Sakti merupakan sentral pembibitan itik di Kabupaten Lebong. Masyarakat di daerah tersebut, selain sebagai petani padi sebagian besarnya juga banyak yang bermata pencaharian sebagai peternak itik guna menjawab kebutuhan masyarakat akan bibit itik, telur sebagai sumber protein, dan demi peningkatan kesejahteraan keluarga mereka. Untuk memenuhi ketersediaan itik di Kecamatan Lebong Sakti dan Kecamatan Amen, dipenuhi dari usaha pembibitan itik modern yang terletak di Desa Ujung Tanjung 2, Desa Garut dan Talang Bunut. Pembibitan itik yang secara tradisional sebagian besar terdapat di Desa Garut. Sistem pembibitan itik modern cara penetasan telur itik dengan menggunakan mesin tetas, sedangkan untuk pembibitan itik tradisional menggunakan induk ayam dan itik. Waktu penetasan tersebut selama 25-28 hari, baik itu untuk pembibitan itik modern maupun pembibitan itik tradisional. Dalam pengolahan usaha ternak, setiap peternak mengupayakan agar hal yang diperoleh secara ekonomis menguntungkan, dimana biaya yang dikeluarkan dapat menghasilkan produksi maksimal. Sehingga pada akhirnya pendapatan peternak akan meningkat, dan dengan meningkatnya pendapatan maka secara otomatis tingkat kesejahteraan peternak tersebut akan meningkat.

Berdasarkan latar belakang dan perumusan masalah di atas, maka penelitian ini bertujuan untuk menghitung besarnya pendapatan usaha pembibitan itik modern dan tradisional pada skala rumah tangga di Kabupaten Lebong, membandingkan pendapatan antara usaha pembibitan itik modern dan tradisional pada skala rumah tangga di Kabupaten Lebong, dan mengukur besarnya tingkat efisiensi usaha pembibitan itik modern dan tradisional pada skala rumah tangga di Kabupaten Lebong.

\section{METODE PENELITIAN}

\section{Lokasi dan Waktu Penelitian}

Lokasi penelitian ini ditentukan secara sengaja atau purposive yaitu di Kecamatan Amen dan Lebong Sakti Kabupaten Lebong. Dengan pertimbangan bahwa Kecamatan Lebong Sakti dan Amen merupakan sentral pembibitan itik di Kabupaten Lebong. Pembibitan itik ini terdiri dari pembibitan itik modern dan tradisional. Penelitian dilaksanakan pada bulan April s/d Mei 2014.

\section{Metode Pengumpulan Data}

Data yang digunakan dalam penelitian ini berupa data primer dan data sekunder. Data primer diperoleh langsung dari pemilik usaha pembibitan itik melalui wawancara langsung dengan menggunakan kuisoner (daftar 
pertanyaan) yang terstruktur. Sedangkan data sekunder diperoleh dari literatur atau pustaka dan data-data dari jurnal dan penelitian terdahulu.

\section{Metode Penentuan Responden}

Berdasarkan hasil pengamatan di lapangan jumlah sampel yang diambil dalam penelitian ini adalah sebanyak 24 orang peternak itik. Diantaranya yaitu 5 orang peternak usaha pembibitan itik modern yang terdapat di Desa Garut 3 orang, Desa Talang Bunut 1 orang dan Desa Ujung Tanjung II 1 orang. Sedangkan peternak usaha pembibitan itik tradisional sebanyak 19 orang yang terdapat keseluruhan di Desa Garut.

\section{Metode Analisis Data}

\section{Menghitung Pendapatan}

Penghitungan pendapatan ini digunakan untuk mengetahui tingkat pendapatan usaha pembibitan itik modern dan tradisional yang diperoleh dari usaha yang dilakukan. Tingkat pendapatan ini dapat dihitung dengan menggunakan rumus sebagai berikut (Soekartawi, 1995):

$$
\begin{aligned}
\mathrm{Pd}_{1}= & \mathrm{TR}-\mathrm{TC} \\
\mathrm{Pd}_{2}= & \mathrm{TR}-\mathrm{TC} \\
\mathrm{TR}_{1}= & \mathrm{Y} . \mathrm{Py} \\
\mathrm{TR}_{2}= & \mathrm{Y} . \mathrm{Py} \\
\mathrm{TC}_{1}= & \mathrm{FC}+\mathrm{VC} \\
\mathrm{TC}_{2}= & \mathrm{FC}+\mathrm{VC} \\
& \text { Dimana: } \\
\mathrm{Pd}= & \text { Pendapatan usaha }(\mathrm{Rp} / 4 \text { bulan } / 100 \text { butir }) \\
\mathrm{TR}= & \text { Penerimaan usaha }(\mathrm{Rp} / 4 \text { bulan } / 100 \text { butir }) \\
\mathrm{TC}= & \text { total biaya usaha }(\mathrm{Rp} / 4 \text { bulan } / 100 \text { butir }) \\
\mathrm{Y}= & \text { Produksi }(\mathrm{Ekor} / 4 \text { bulan } / 100 \text { butir }) \\
\mathrm{Py}= & \text { Harga output }(\mathrm{Rp} / 4 \text { bulan } / 100 \text { butir }) \\
\mathrm{VC}= & \text { Biaya variabel }(\mathrm{Rp} / 4 \text { bulan } / 100 \text { butir }) \\
\mathrm{FC}= & \text { Biaya tetap }(\mathrm{Rp} / 4 \text { bulan } / 100 \text { butir }) \\
1 & =\text { Usaha pembibitan itik modern } \\
2 \quad= & \text { Usaha pembibitan itik tradisional }
\end{aligned}
$$

\section{Uji Beda Pendapatan Usaha Pembibitan Itik Modern dan Tradisional}

Untuk mengetahui apakah ada perbedaan rata-rata pendapatan antara peternak pembibitan itik modern dan tradisional digunakan analisis uji beda nilai tengah (uji t) dengan tingkat kepercayaan 95\% (Djarwanto dan Subagyo dalam Fitrah, 2013). Adapun rumus $t_{\text {hitung }}$ yang digunakan adalah: 


$$
\begin{aligned}
& S_{1}^{2}=\frac{\sum_{n-1}^{n}\left(x_{1}-\bar{x}_{1}\right)^{2}}{n_{1}-1} \\
& S_{2}^{2}=\frac{\sum_{n-1}^{n}\left(x_{2}-\bar{x}_{2}\right)^{2}}{n_{2}-1} \\
& S P^{2}=\frac{\left(n_{1}-1\right) S_{1}^{2}+\left(n_{2}-1\right) S_{2}^{2}}{\left(n_{1}+n_{2}\right)-2} \\
& t=\frac{\overline{x_{1}-x_{2}}}{\sqrt{S P^{2}\left(\frac{1}{n_{1}}+\frac{1}{n_{2}}\right)}}
\end{aligned}
$$

Dimana:

$X_{1} \quad=$ Pendapatan usaha pembibitan itik modern (Rp/4 bulan/100 butir)

$X_{2} \quad=$ Pendapatan usaha pembibitan itik tradisional (Rp/4 bulan/100 butir)

$\bar{X}_{1} \quad=$ Rata-rata pendapatan usaha pembibitan itik modern (Rp/4 bulan/100 butir)

$\bar{X}_{2} \quad=$ Rata-rata pendapatan usaha pembibitan itik tradisional $(\mathrm{Rp} / 4$ bulan/100 butir)

$\mathrm{S}_{1}{ }^{2} \quad=$ Keragaman pendapatan usaha pembibitan itik modern

$\mathrm{S}_{2}{ }^{2}=$ Keragaman pendapatan usaha pembibitan itik tradisional

$\mathrm{SP}^{2} \quad=$ Keragaman sampel

$\mathrm{n}_{1} \quad=$ Jumlah sampel usaha pembibitan itik modern

$\mathrm{n}_{2} \quad=$ Jumlah sampel pembibitan itik tradisional

Maka prosedur uji t tersebut sebagai berikut:

$\mathrm{H}_{\mathrm{o}}: \mu_{1} \leq \mu_{2}$

$\mathrm{H}_{\mathrm{a}}: \mu_{1}>\mu_{2}$

Keterangan:

$\mu_{1} \quad=$ Rata-rata pendapatan usaha pembibitan itik modern

$\mu_{2} \quad=$ Rata-rata pendapatan usaha pembibitan itik tradisional

Selanjutnya akan diuji pada taraf $95 \%$ dengan kriteria pengujian sebagai berikut:

1. $\mathrm{t}$ hitung $>\mathrm{t}$ tabel maka keputusanya: terima $\mathrm{H}_{\mathrm{a}}$ dan tolak $\mathrm{H}_{\mathrm{o}}$ artinya pendapatan usaha pembibitan itik modern lebih besar dari pada pendapatan usaha pembibitan itik tradisional. 
2. $\mathrm{t}$ hitung $\leq \mathrm{t}$ tabel maka keputusanya: tolak $\mathrm{H}_{\mathrm{a}}$ dan terima $\mathrm{H}_{\mathrm{o}}$ artinya pendapatan usaha pembibitan itik modern lebih kecil sama dengan pendapatan usaha pembibitan itik tradisional.

\section{Mengukur Tingkat Efisiensi Usaha}

$\mathrm{R} / \mathrm{C}$ (Cost Ratio) dikenal sebagai perbandingan antara penerimaan dan biaya usaha pembibitan itik modern (Soekartawi, 2002). Secara matematis dirumuskan sebagai berikut:

$$
\begin{array}{ll}
\mathrm{R} / \mathrm{C}_{1}=\frac{T R}{T C} & \text { atau } \mathrm{R} / \mathrm{C}_{1}=\frac{(P y . Y)}{F C+V C} \\
\mathrm{R} / \mathrm{C}_{2}=\frac{T R}{T C} & \text { atau } \mathrm{R} / \mathrm{C}_{2}=\frac{(P y . Y)}{F C+V C}
\end{array}
$$

Dimana:

$\mathrm{R}=$ Penerimaan usaha $(\mathrm{Rp} / 4$ bulan $/ 100$ butir $)$

Py = Harga output (Rp/4 bulan/100 butir)

$\mathrm{Y}=$ Produksi (Ekor $/ 4$ bulan/100 butir)

$\mathrm{TC}=$ Total biaya $(\mathrm{Rp} / 4$ bulan/100 butir $)$

$\mathrm{VC}=$ Biaya variabel $(\mathrm{Rp} / 4$ bulan/100 butir $)$

$\mathrm{FC}=$ Biaya tetap $(\mathrm{Rp} / 4$ bulan/100 butir $)$

1 = Usaha pembibitan itik modern

2 = Usaha pembibitan itik tradisional

Dengan ketentuan:

- Jika $R / C$ ratio $>1$, maka usaha sudah efesien dan menguntungkan.

- Jika $R / C$ ratio $<1$, maka usaha tidak efesien dan tidak menguntungkan (rugi).

- Jika $\mathrm{R} / \mathrm{C}$ ratio $=1$, maka usaha tidak menguntungkan dan tidak merugikan

\section{HASIL DAN PEMBAHASAN}

\section{Karakteristik Responden Usaha Pembibitan Itik Modern dan Tradisional}

\section{Umur}

Rata-rata umur peternak pembibitan itik modern yaitu 44,6 tahun dan peternak pembibitan itik tradisional 39,26 tahun. Bila dilihat dari keadaan umur tersebut peternak pembibitan tradisional dan modern termasuk dalam golongan produktif. Pada usia produktif peternak pembibitan akan memberikan hasil yang maksimal jika dibandingkan pada usia di bawah produktif.

\section{Pendidikan}

Pendidikan merupakan salah satu faktor yang ikut menentukan dalam keberhasilan suatu usaha. Pendidikan seseorang umumnya mempengaruhi 
cara dan pola fikir dalam mengelola usahanya dan akan berpartisipasi aktif juga dalam suatu kegiatan. Rata-rata pendidikan formal yang ditempuh peternak pembibitan itik modern adalah 10,8 tahun setara dengan tingkat pendidikan SLTA, sedangkan rata-rata pendidikan formal peternak pembibitan itik tradisional adalah 9 tahun setara dengan SLTP.

\section{Jumlah Anggota Keluarga}

Rata-rata jumlah tanggungan keluarga peternak pembibitan itik modern dan tradisional sebanyak 4 orang. Jumlah tanggungan keluarga berpengaruh pada tingkat pengeluaran dalam memenuhi kebutuhan keluarga. Semakin besar jumlah tanggungan keluarga maka akan semakin besar pula pengeluaran dalam memenuhi kebutuhan keluarga dan sebaliknya. Secara tidak langsung hal ini memberikan motivasi yang kuat bagi peternak untuk berupaya meningkatkan kegiatan usahanya sehingga kebutuhan keluarga terpenuhi.

\section{Pengalaman}

Rata-rata pengalaman peternak pembibitan itik modern adalah 20,8 tahun dan peternak pembibitan itik tradisional 16,37 tahun. Pengalaman dalam melakukan usaha pembibitan itik akan memberikan pengetahuan lebih luas dalam melakukan kegiatan usaha pembibitan. Peternak yang berpengalaman akan lebih efisien dan produktif dalam mengelola usahanya dibandingkan dengan peternak yang belum berpengalaman, karena peternak tersebut mampu mengatasi masalah-masalah yang timbul dalam kegiatan usaha pembibitan itiknya berdasarkan dari pengalaman sebelumnya yang sudah pernah dilakukanya.

\section{Jumlah Itik yang Dihasilkan}

Rata-rata jumlah itik yang dihasilkan peternak pembibitan itik modern yaitu sebanyak 419 ekor dan peternak pembibitan itik tradisional sebanyak 87 ekor.

\section{Tingkat Keberhasilan}

Rata-rata tingkat keberhasilan usaha pembibitan itik modern yaitu sebesar $76,27 \%$ dan usaha pembibitan itik tradisional sebesar $88,99 \%$. Artinya setiap peternak pembibitan itik modern dalam menetaskan telur tetas sebanyak 100 butir telur tetas, maka akan menghasilkan sebanyak 76 butir telur tetas yang menetas. Begitu juga untuk usaha pembibitan itik tradisional, setiap menetaskan telur tetas sebanyak 100 butir maka akan menghasilkan sebanyak 88 butir telur tetas yang menetas. 
ISSN: $1412-8837$

\section{Biaya Usaha Pembibitan Itik}

\section{Biaya Variabel Pembibitan Itik}

Besarnya rata-rata biaya variabel yang dikeluarkan untuk usaha pembibitan itik modern dan tradisional dapat dilihat pada Tabel 1 berikut:

Tabel 1. Rata-Rata Biaya Variabel Pembibitan Itik Modern dan Tradisional (Rp/4 bulan/100 butir)

\begin{tabular}{|c|c|c|c|c|c|}
\hline No & Biaya Variabel & $\begin{array}{c}\text { Modern } \\
\text { (Rp/4 bln/100 } \\
\text { butir) }\end{array}$ & $\%$ & $\begin{array}{c}\text { Tradisional } \\
\text { (Rp/4 bln/100 } \\
\text { butir) }\end{array}$ & $\%$ \\
\hline 1 & Biaya telur tetas & $164.000,00$ & 13,05 & $160.000,00$ & 11,49 \\
\hline \multirow[t]{5}{*}{2} & Biaya pakan & & & & \\
\hline & Konsentrat & $182.880,00$ & & $213.221,05$ & - \\
\hline & Dedak & $70.000,00$ & & $106.589,47$ & - \\
\hline & Rumbio & $160.000,00$ & & $160.000,00$ & - \\
\hline & Total biaya pakan & $412.880,00$ & 2,86 & $479.810,52$ & 34,46 \\
\hline 3 & $\begin{array}{l}\text { Biaya pemasaran } \\
\text { dan transportasi }\end{array}$ & $9.000,00$ & 0,72 & $9.000,00$ & 0,65 \\
\hline 4 & Biaya TK & $624.428,57$ & 9,71 & $743.646,62$ & 53,40 \\
\hline 5 & Biaya listrik & $46.000,00$ & 0,66 & - & - \\
\hline \multicolumn{2}{|c|}{ Total biaya variabel } & $1.256 .308,57$ & 100 & $1.392 .457,14$ & 100,00 \\
\hline
\end{tabular}

Sumber: Data Primer Diolah, 2014

Biaya Pembelian Telur Tetas

Jumlah telur tetas (telur itik) yang digunakan untuk pembibitan itik modern dan tradisional adalah sebanyak 100 butir. Rata-rata harga telur tetas yang dibeli oleh peternak pembibitan itik modern sebesar Rp. 1.640,- per butir, sedangkan harga telur tetas yang dibeli oleh peternak pembibitan itik tradisional sebesar Rp. 1.600,- per butir. Dari Tabel 1 diketahui bahwa rata-rata biaya yang dikeluarkan untuk pembelian telur tetas adalah sebesar Rp. 164.000,- untuk pembibitan itik modern dan Rp. 160.000,-untuk pembibitan itik tradisional.

Biaya Pakan

Dalam usaha pembibitan itik, pemberian pakan merupakan hal yang mutlak agar pertumbuhan itik dapat berlangsung dengan cepat. Jenis pakan yang digunakan adalah konsentrat (pur), dedak dan rumbio. Berdasarkan 
Tabel 2 diketahui bahwa rata-rata biaya pakan sebesar Rp. 412.880,- selama empat bulan untuk pembibitan itik modern, sedangkan rata-rata biaya pakan pembibitan itik tradisional sebesar Rp. 479.810,52 selama empat bulan. Perbedaan jumlah biaya pakan antara pembibitan itik modern dan tradisional karena adanya perbedaan pemberian pakan, seperti diketahui bahwasanya usaha pembibitan itik tradisional dalam melakukan usahanya atau melakukan penetasan telur tetas dengan menggunakan induk ayam dan itik. Sehingga dalam usaha selama empat bulan tersebut peternak pembibitan itik tradisional memberi pakan pada induk ayam dan itiknya juga. Pemberian pakan pada itik atau indukan diberikan secara rutin oleh peternak, selama empat bulan ratarata jumlah pakan yang diberikan hingga mencapai 22,86 Kg pur, 2 karung dedak atau $70 \mathrm{~kg}$ (2 karung) dan 4 potong rumbio untuk pembibitan itik modern. Sedangkan pembibitan itik tradisional rata-rata jumlah pakan yang diberikan mencapai 26,7 Kg pur, 4 karung dedak atau $140 \mathrm{Kg}$ untuk itik yang dihasilkan dan induk ayam/itik serta 4 potong rumbio.

\section{Biaya Pemasaran dan Transportasi}

Biaya pemasaran dan transportasi merupakan biaya yang dikeluarkan oleh peternak pembibitan itik pada saat pemasaran hasil produksi (itik), pembelian telur tetas dan pembelian pakan. Dari Tabel 2 dapat dilihat bahwa rata-rata biaya pemasaran dan transportasi pembibitan itik modern maupun tradisional adalah sebesar Rp. 9.000,- yang terdiri dari biaya pulsa dan bensin. Untuk pulsa sebesar Rp. 2.000,- dan bensin Rp. 7.000,- selama empat bulan.

\section{Biaya Tenaga Kerja}

Rata-rata biaya penggunaan tenaga kerja pria dan wanita dalam usaha pembibitan itik di Kabupaten Lebong adalah sebesar Rp. 624.428,57 untuk pembibitan itik modern dan biaya tenaga kerja pembibitan itik tradisional sebesar Rp. 743.646,62 selama empat bulan. Rata-rata biaya penggunaan tenaga kerja pada usaha pembibitan itik tradisional lebih besar dari pada pembibitan itik modern. Adanya perbedaan ini karena pada usaha pembibitan itik tradisional terdapat biaya tenaga kerja pemberian pakan pada induk ayam dan itik, sedangkan pada usaha pembibitan itik modern tidak terdapat biaya pemberian pakan selain dari pemberian pakan pada anak itik. Karena usaha pembibitan itik modern dalam melakukan usaha pembibitan itik dengan menggunakan mesin tetas, sedangkan usaha pembibitan itik tradisional menggunakan induk ayam dan itik.

\section{Biaya Listrik}

Listrik merupakan salah satu faktor produksi penting untuk kegiatan usaha pembibitan itik. Dalam usaha pembibitan itik modern dan tradisional di Kabupaten Lebong, biaya penggunaan listrik hanya dipakai oleh peternak pembibitan itik modern dan penggunaan listrik pada proses penetasan yaitu 
selama 25-28 hari dalam empat bulan. Perlu diketahui bahwasanya usaha pembibitan itik modern dalam melakukan penetasan telur tetas menggunakan mesin tetas, sedangkan usaha pembibitan tradisional menggunakan induk ayam dan itik sehingga tidak menggunakan biaya listrik. Dari Tabel 2 rata-rata biaya penggunaan listrik selama 25-28 hari pada usaha pembibitan itik modern yaitu sebesar Rp. 46.000,- selama empat bulan.

\section{Biaya Tetap Pembibitan Itik}

Besarnya biaya tetap yang dikeluarkan usaha pembibitan itik modern dan tradisional di Kabupaten Lebong dapat dilihat pada Tabel 3 berikut.

\begin{tabular}{|c|c|c|c|c|}
\hline Biaya Tetap & $\begin{array}{c}\text { Modern } \\
\text { (Rp/4 bln/100 } \\
\text { butir) }\end{array}$ & $\%$ & $\begin{array}{c}\text { Tradisional } \\
\text { (Rp/4 bln/100 } \\
\text { butir) }\end{array}$ & $\%$ \\
\hline $\begin{array}{l}\text { Penyusutan induk ayam } \\
\text { dan itik } \\
\text { Penyusutan peralatan }\end{array}$ & - & & $27.719,30$ & 50,50 \\
\hline kandang induk/anak itik & $31.250,00$ & 39,70 & $20.833,33$ & \\
\hline tempat pakan & $1.583,33$ & 2,01 & $2.222,22$ & \\
\hline keranjang telur & 833,33 & 1,06 & $1.125,73$ & \\
\hline telephon & $3.333,33$ & 4,23 & $2.719,30$ & \\
\hline mesin tetas & $38.833,33$ & 49,33 & - & \\
\hline kotak anak itik & $2.000,00$ & 2,54 & - & \\
\hline kotak tempat telur & 222,22 & 0,28 & - & \\
\hline bola lampu & 666,67 & 0,85 & - & \\
\hline Total biaya penyusutan & $78.722,22$ & 100,00 & $26.900,58$ & 49,50 \\
\hline Total biaya tetap & $78.722,22$ & 100,00 & $54.619,88$ & 100,00 \\
\hline
\end{tabular}

Sumber: Data Primer Diolah, 2014

Peralatan yang digunakan oleh peternak pembibitan itik modern dan tradisional di daerah penelitian yaitu kandang, tempat pakan, keranjang telur, telephon, mesin tetas, kotak untuk anak itik, kotak tempat telur dan bola lampu. Untuk pembibitan itik tradisional dalam melakukan kegiatan usaha pembibitan itik penetasan telur menggunakan induk ayam dan itik sehingga biaya penyusutan induk ayam dan itik diperhitungkan juga karena masih tanggung jawab peternak. Rata-rata total biaya penyusutan peralatan yang dikeluarkan oleh peternak pembibitan itik modern yaitu sebesar Rp. 78.722,22 sedangkan pada peternak pembibitan itik tradisional sebesar Rp. 54.619,88 selama empat bulan. Biaya penyusutan peralatan (biaya tetap) yang dikeluarkan oleh usaha pembibitan itik modern lebih besar dari pembibitan itik tradisional, hal ini karena adanya perbedaan dalam penggunaan peralatan usaha. 


\section{Total Biaya Pembibitan Itik}

Total biaya adalah seluruh biaya yang dikeluarkan selama proses usaha pembibitan itik modern maupun tradisional berlangsung yaitu penjumlahan biaya tetap dan biaya variabel yang dikeluarkan.

Tabel 4. Rata-Rata Biaya Usaha Pembibitan Itik Modern dan Tradisional (Rp/4 bulan/100 butir)

\begin{tabular}{llrr}
\hline \multirow{2}{*}{ No } & Total Biaya & \multicolumn{1}{c}{ Modern } & \multicolumn{1}{c}{ Tradisional } \\
& (Rp/4 bln/100 butir) & (Rp/4 bln/100 butir $)$ \\
\hline 1 & Biaya variabel & $1.256 .308,57$ & $1.392 .457,14$ \\
2 & Biaya tetap & $78.722,22$ & $54.619,88$ \\
\hline \multicolumn{2}{l}{ Total biaya } & $1.335 .030,79$ & $1.447 .077,02$ \\
\hline
\end{tabular}

Sumber: Data Primer Diolah, 2014

Dari Tabel 4 dapat dilihat bahwa total biaya yang dikeluarkan oleh usaha pembibitan itik modern dan tradisional selama empat bulan adalah sebesar Rp. 1.335.030,79 untuk pembibitan itik modern dan total biaya pembibitan itik tradisional sebesar Rp. 1.447.077,02 yang terdiri dari biaya variabel dan biaya tetap.

\section{Produksi dan Penerimaan Pembibitan Itik}

Tabel 5. Rata-Rata Produksi Dan Penerimaan Usaha Pembibitan Itik Modern dan Tradisional ( $\mathrm{Rp} / 4$ bulan/100 butir)

\begin{tabular}{clrrr}
\hline \multirow{2}{*}{ No } & \multicolumn{1}{|c}{ Uraian } & \multicolumn{1}{c}{ Produksi } & \multicolumn{1}{c}{ Harga } & \multicolumn{1}{c}{ Penerimaan } \\
\cline { 2 - 5 } & (Ekor/Produksi) & (Rp/Ekor) & (Rp/Produksi) \\
\hline 1 & $\begin{array}{l}\text { Pembibitan itik } \\
\text { modern }\end{array}$ & 76,20 & 35.000 & $2.667 .000,00$ \\
2 & $\begin{array}{l}\text { Pembibitan itik } \\
\text { tradisional }\end{array}$ & 88,84 & 35.000 & $3.109 .473,68$ \\
\hline
\end{tabular}

Sumber: Data Primer Diolah, 2014

Dalam penelitian ini jumlah skala usaha disamakan yaitu menetaskan 100 butir telur tetas baik untuk usaha pembibitan itik modern maupun usaha pembibitan itik tradisional. Produksi pembibitan itik yang diukur dalam penelitian ini adalah itik yang telah siap dijual yang sudah berumur tiga bulan, dalam artian rata-rata penjualan itik berumur dua bulan setengah sampai dengan tiga bulan dengan catatan pada umur tiga bulan itik telah terjual semuanya. Jumlah produksi antara usaha pembibitan itik modern dan tradisional terdapat perbedaan karena adanya tingkat keberhasilan kedua usaha tersebut. Dari hasil penelitian tingkat keberhasilan usaha pembibitan itik modern sebesar $76,20 \%$ dan usaha pembibitan itik tradisional sebesar $88,84 \%$. Artinya setiap peternak pembibitan itik modern dalam menetaskan telur tetas sebanyak 100 butir, maka akan menghasilkan sebanyak 76 ekor bibit itik yang siap untuk dijual. Begitu juga untuk usaha pembibitan itik tradisional, setiap 
menetaskan telur tetas sebanyak 100 butir maka akan menghasilkan sebanyak 88 ekor bibit itik yang siap untuk dijual. Rata-rata harga jual itik per ekornya pada saat penelitian adalah Rp. 35.000,- pada peternak pembibitan itik modern maupun tradisional. Rata-rata penerimaan pada usaha pembibitan itik modern adalah sebesar Rp. 2.667.000,- selama empat bulan, sedangkan rata-rata penerimaan usaha pembibitan itik tradisional sebesar Rp. 3.109.473,68 selama empat bulan.

\section{Pendapatan Usaha Pembibitan Itik}

Pendapatan merupakan selisih antara total penerimaan dengan total biaya. Besarnya pendapatan ditentukan oleh besarnya penerimaan dan biaya yang dikeluarkan.

Tabel 6. Pendapatan Usaha Pembibitan Itik Modern dan Tradisional (Rp/4 bulan/100 butir)

\begin{tabular}{ccrr}
\hline \multirow{2}{*}{ No } & \multirow{2}{*}{ Uraian } & $\begin{array}{c}\text { Modern } \\
(\mathrm{Rp} / 4 \mathrm{bln} / 100 \text { butir })\end{array}$ & $\begin{array}{c}\text { Tradisional } \\
(\mathrm{Rp} / 4 \mathrm{bln} / 100 \text { butir })\end{array}$ \\
& Penerimaan (TR) & $2.667 .000,00$ & $3.109 .473,68$ \\
2 & Total biaya (TC) & $1.335 .030,79$ & $1.447 .077,02$ \\
\hline \multicolumn{2}{c}{ Pendapatan (PD) } & $\mathbf{1 . 3 3 1 . 9 6 9 , 2 1}$ & $\mathbf{1 . 6 6 2 . 3 9 6 , 6 6}$ \\
\hline
\end{tabular}

Sumber: Data Primer Diolah, 2014

Pada Tabel 6 di atas dapat dilihat bahwa rata-rata pendapatan usaha pembibitan itik modern di Kabupaten Lebong adalah sebesar Rp.1.331.969,21 selama empat bulan, sedangkan rata-rata pendapatan pembibitan itik tradisional adalah sebesar Rp. 1.662.396,66 selama empat bulan. Pendapatan yang diperoleh usaha pembibitan itik tradisional lebih besar dari pada usaha pembibitan itik modern. Perbedaan pendapatan ini terjadi karena adanya tingkat keberhasilan yang berbeda antara kedua usaha tersebut.

\section{Uji Beda Pendapatan Usaha Pembibitan Itik Modern dan Tradisional}

Hasil uji beda pendapatan yang dilakukan pada usaha pembibitan itik modern dan tradisional di Kabupaten Lebong diperoleh nilai $t$ hitung usaha sebesar -17,22. Angka tersebut lebih kecil dari nilai t tabel yaitu 1,70, maka keputusanya: tolak $\mathrm{H}_{\mathrm{a}}$ dan terima $\mathrm{H}_{\mathrm{o}}$ artinya pendapatan usaha pembibitan itik modern lebih kecil sama dengan pendapatan usaha pembibitan itik tradisional. Perbedaan nilai pendapatan pada usaha pembibitan itik modern dan tradisional karena adanya perbedaan tingkat keberhasilan kedua usaha tersebut. Dari hasil penelitian tingkat keberhasilan usaha pembibitan itik modern sebesar $76,20 \%$ dan usaha pembibitan itik tradisional sebesar $88,84 \%$. 


\section{Efisiensi Usaha Pembibitan Itik Modern dan Tradisional}

Untuk melihat apakah usaha pembibitan itik modern dan tradisional di Kabupaten Lebong sudah efisien atau belum, maka kita dapat melihatnya dari hasil perhitungan efisiensi usaha yaitu $\mathrm{R} / \mathrm{C}$ ratio.

\section{Tabel 7. Tingkat Efisiensi Usaha Pembibitan Itik Modern dan Tradisional} (Rp/4 bulan/100 butir)

\begin{tabular}{clrr}
\hline \multirow{2}{*}{ No } & \multicolumn{1}{c}{ Uraian } & \multicolumn{1}{c}{ Modern } & \multicolumn{1}{c}{ Tradisional } \\
& (Rp/4 bln/100 butir) & (Rp/4 bln/100 butir) \\
\hline 1 & Penerimaan (TR) & $2.667 .000,00$ & $3.109 .473,68$ \\
2 & Total biaya (TC) & $1.335 .030,79$ & $1447.077,02$ \\
\hline & R/C ratio & 2,00 & 2,15 \\
\hline
\end{tabular}

Sumber: Data Primer Diolah, 2014

Untuk menghitung besarnya tingkat efisiensi usaha digunakan metode $\mathrm{R} / \mathrm{C}$ ratio, dimana $\mathrm{R} / \mathrm{C}$ ratio merupakan perbandingan antara penerimaan dan biaya. Apabila R/C ratio lebih besar dari satu berarti usaha tersebut sudah menguntungkan (Soekartawi, 2002). Hasil perhitungan $\mathrm{R} / \mathrm{C}$ ratio usaha pembibitan itik modern yaitu dengan nilai $\mathrm{R} / \mathrm{C}$ ratio $>1$ yaitu sebesar 2,00. Artinya bahwa setiap Rp. 1.- biaya yang dikeluarkan untuk usaha pembibitan itik modern akan menghasilkan penerimaan usaha sebesar Rp 2,00,-. Sedangkan nilai $\mathrm{R} / \mathrm{C}$ ratio pembibitan itik tradisional sebesar 2,15 artinya bahwa setiap Rp. 1.- biaya yang dikeluarkan untuk usaha pembibitan itik tradisional akan menghasilkan penerimaan usaha sebesar Rp 2,15,-. Sehingga dengan demikian usaha pembibitan itik di Kabupaten Lebong sudah efisien, baik usaha pembibitan itik modern maupun usaha pembibitan itik tradisional. Perbedaan efisiensi antara usaha pembibitan itik modern dengan usaha pembibitan itik tradisional karena adanya tingkat keberhasilan yang berbeda antara kedua usaha tersebut.

\section{SIMPULAN DAN SARAN}

\section{Simpulan}

1. Berdasarkan hasil penelitian rata-rata pendapatan usaha pembibitan itik modern adalah sebesar Rp.1.331.969,21 selama empat bulan, sedangkan rata-rata pendapatan usaha pembibitan itik tradisional sebesar Rp. 1.662.396,66 selama empat bulan.

2. Setelah dilakukan uji beda pendapatan antara usaha pembibitan itik modern dan tradisional, pendapatan usaha pembibitan itik modern lebih kecil sama dengan pendapatan usaha pembibitan itik tradisional dimana perbedaan tersebut nyata pada taraf kepercayaan $95 \%$. 
3. Nilai rata-rata hasil analisis $\mathrm{R} / \mathrm{C}$ ratio pada usaha pembibitan itik modern di Kabupaten Lebong adalah sebesar 2,00 sedangkan R/C ratio pembibitan itik tradisional sebesar 2,15.

\section{Saran}

Disarankan kepada peternak pembibitan itik tradisional yang memiliki modal relatif kecil, agar tetap mempertahankan usaha pembibitan itiknya, berdasarkan hasil penelitian pendapatan usaha pembibitan itik tradisional lebih besar dari pada usaha pembibitan itik modern, meskipun skala usahanya masih rumah tangga. Sedangkan untuk peternak usaha pembibitan itik modern dalam melakukan usahanya agar lebih ditingkatkan lagi skala produksinya. Perlu diketahui bahwasanya semakin besar skala produksi dalam melakukan usaha maka akan semakin besar tingkat pendapatanya, begitupun dengan tingkat efisiensinya.

\section{DAFTAR PUSTAKA}

Apriyantono, Anton. 2011. Pedoman Budidaya Itik Pedaging yang Baik. http:// pedoman-budidaya-itik-pedaging-yang.html. Di akses Tanggal 10 Februari 2014.

Fitrah, Andri Anto. 2013. Analisis Finansial Usaha Tani Jagung Petani Peserta dan Non Peserta Program Pengembangan Usaha Agribisnis Pedesaan (PUAP) di Kelurahan Padang Serai Kecamatan Kampung Melayu Kota Bengkulu. Skripsi Jurusan Sosial Ekonomi Pertanian, Fakultas Pertanian, Universitas Bengkulu (Tidak Dipublikasikan).

Juarini E., Sumanto, B. W.Ibowo dan L.H. Prasetyo. 2004. Evaluasi Bibit Itik Niaga Petelur. Ditingkat Peternak. Laporan Akhir. Balai Penelitian Ternak Bogor.

Soekartawi. 1995. Analisis Usahatani. Universitas Indonesia Press. Jakarta.Soekartawi, S. T. 1997. Industri pertanian terpadu, konsep dan aplikasinya. Jurnal Agribisnis. Vol (I) Hal: 166-169.

Soekartawi. 2002. Prinsip Dasar Ekonomi Pertanian Teori dan Aplikasinya. Raja Grafindo Persada. Jakarta. 